\title{
Iraq's popular mobilisation units: intra-sectarian rivalry and Arab Shi'a mobilisation from the 2003 invasion to Covid-19 pandemic
}

\author{
Ibrahim Al-Marashi ${ }^{1}$ (D)
}

Published online: 12 June 2021

(c) The Author(s), under exclusive licence to Springer Nature Limited 2021

\begin{abstract}
The Popular Mobilisation Units' (PMU) rise in Iraq resulted from a de facto, post2003 hybridization of security governance, opposed to an emergency measure to combat Islamic State after 2014. Rather than a cohesive sectarian movement, the PMU moniker granted a government veneer to an array of pre-existing or new militias, representing a decentralized Shi'a Arab mobilisation prior to 2014, symptomatic of Iraq's divisive patronage politics. Perceived by the US and the Arab world as 'pro-Iranian Shi'a militias', as a spoiler to Iraq's sovereignty, and an Iranian means of securing its control over Baghdad, while some militias began as NSAAs, the PMU have evolved into quasi-state actors by becoming part of the state, but not under its complete control. Ultimately, their power within Iraq is constrained by the other political institutions, such as the electoral cycle, the Shi' a clerical establishment, and a protest movement, in addition to a pandemic, Covid-19.
\end{abstract}

Keywords Iraq · Iran · ISIS · Shi’a militias · Saddam Hussein · Covid-19

\section{Introduction}

The new decade of 2020 in the Middle East was augured in with an American drone strike outside of Baghdad's international airport that killed Qassem Soleimani, the commander of Iran's expeditionary Revolutionary Guards Quds Force, as well as Abu Mahdi Muhandis, an Iraqi Popular Mobilization Unit (PMU) leader. Soleimani had established or supported an array of non-state armed actors (NSAA) in the region, ranging from Yemen, Syria, Lebanon, and Iraq. The assassination, part of the escalating tensions between a superpower and regional power over the latter's nuclear program, also killed Soleimani's Iraqi

Ibrahim Al-Marashi

Ibrahim.almarashi@gmail.com

1 Department of History, California State University San Marcos, 333 S. Twin Oaks Valley Rd.,

San Marcos, CA 92096-0001, USA 
protégé, Muhandis, whose career began as a leader of an Iraqi NSAA, the Hizballah Brigades (katai'b hizballah), yet rose to become an official with the Iraqi state. Those events exemplify the PMU's interactions with this journal's themed issues of Middle Eastern NSAAs interweaving across notions of sovereignty, geopolitics and territoriality, as well as symptomatic of the constrained and contested nature of sovereignty, in this case Iraqi.

Trump's assassination of Soleimani is situated within a consistent American double standard regarding Shi' a militias after 2003 and their post-2014 PMU incarnation, as Washington considers the militias of the Kurdistan Regional Government (KRG) as allies and thus legitimate, while the PMU are deemed either 'proxies' and 'agents' of the Islamic Republic of Iran, even though both essentially emerged as NSAAs that have been incorporated into quasi-official status within the Iraqi state. The US has viewed Iraq's Shi' a militias as a problematic phenomenon that emerged after 2003 and only worsened after the Islamic State of Iraq and Syria (ISIS) invasion of 2014, as spoilers to the Iraq's state building process and a challenge to American efforts to rebuild the Iraqi military. The other double standard was expressed in the aftermath of the 2014 ISIS invasion. Then, the Iraqi government invited an American advisory mission to assist the Iraqi military and deploy to an air force base at 'Ain al-Asad to provide air cover during combat operations against ISIS. After 2014, another foreign assistance mission enhanced its role in Iraq, even though its rarely described as such-Soleimani's Quds Force, which also provided training to Iraq's militias.

The US, particularly under the Trump administration, conflates Iran and the PMU as a single threat, when Iraqi and Iranian Shi' ism have had a history of rivalry. Rather than examining the Iraqi Shi' a militia's relationship with Iran based on an inherent link due to the shared sectarian affiliation, some, but not all PMUs share a mutually beneficial reciprocal relationship with Iran that can be characterized as the political expediency and exploitation of shared sectarian-confessional identities, where the interests of both parties converge in maintaining and pursuing Shi'a power in Iraq. However, Iraqi Shi'a militias have sought to out their own agency and pursued agendas independently of Tehran, blurring the distinction between 'proxy' and militias who engage in an alliance of convenience with the Islamic Republic.

This paper argues that the state moniker of the PMU, as an ad hoc title that bestowing a de facto government veneer to a range of militias, is more precisely the outcome a decentralized Shi'a Arab paramilitary mobilisation. The PMU is an abbreviation for the Arabic al-hashd al-sha'bi, with hashd meaning 'mobilisation', while the latter term connotes 'popular' as in the 'people'. The official Arabic title does not specify the term 'units', which was added by Western observers. Qais al-Khaz'ali, leader of the League of the Righteous (asa'ib ahl al-haqq) militia, highlighted the significance of the semantics of hashd, envisioning the notion encompassing sectors of civil society that would include a women's hashd to a university-level hashd. He even declared he would like to change his own name to 'Hashd ibn Hashd al-Hashdawi' (Haddad 2018, p. 14), literally 'Mobilization, son of Mobilization, Mobilizing.' Indeed, the Hashd would mobilise in terms of reconstruction, providing health care during the Covid-19 pandemic, as well as partaking in the black market. 
The ad hoc process in which the Hashd emerged has led to internal divisions, dispelling any notion that it can be demarcated as a cohesive sectarian movement or a single Iranian proxy. Some of the Hashd units have articulated a symbiotic Shi'a Iraqi nationalism that precludes complete Iranian control over this collective body. The Hashd is also rife with intra-sectarian political rivalry and even armed clashes amongst the array of militias and the greater Iraqi Shi'a population at large. These tensions represent the first level in which the Hashd power is contested; the umbrella nature of the organisation itself, which leads to conflicts with other militias. Second, the factions within the Hashd movement seek maximize power at the state level. After the 2018 elections, the Iraqi government and the militias developed a symbiotic relationship, with their commanders serving as members of parliament and cabinet ministers, fusing with the state, and jostling for power with the Prime Minister, and other parties in parliament. Finally, units of the Hashd interact with Iraqi civil society, from Iraq's clerical establishment to a predominantly Shi'a protest movement, representing a national intra-Shi' a conflict. Since the expulsion of ISIS from Mosul in late 2017 the legitimacy of the Hashd as an institution has been challenged, particularly by the October 2019 protest. Thus, while the Hashd represented a Shi'a mobilisation, the sustained protest movement represented an alternative grassroots Shi' a mobilisation that challenged the Hashd's core narrative. Since then some of the Hashd factions' alliance with Iran has become as a liability to their nationalist credentials among Iraq's Arab Shi'a, not just on the streets but also between within the Iraqi Shi'a clerical establishment, which seeks to maintain its autonomy vis-àvis the Islamic Republic.

Ultimately, the Hashd coalition represents a plurality of Shi' a actors which seek to legitimize and negotiate power among Iraqi Shi' a religious networks, rival Shi'a parliamentary parties, and the greater populace. The Trump administration's military strikes sought to limit the power of the Hashd, but by violating Iraq's sovereignty it strengthened and emboldened the pro-Iranian elements within the body, reconciling the Hashd bloc in parliament with its rival Shi' a parties aligned to Iraqi cleric Muqtada al-Sadr, allowing them collectively to renew their agenda for an American withdrawal from Iraq. The Covid-19 pandemic emerged as an independent variable within these interlocking relationships, striking Iran, the benefactor of several Hashd factions, yet also dispersing the protests, offering the Hashd a respite and a chance for these militias to brandish their public health capacity.

\section{Conceptualizing the Hashd}

The rebuilding process of the Iraqi armed forces after 2003 and prior to the ISIS invasion reflected both an American and Iraqi state-centric view that aspired for Iraq's national army to achieve the monopoly on the use of armed violence within the nation, informed by Max Weber's oft quoted definition as the state serving as the ultimate claimant to 'the monopoly of the legitimate use of violence within a given territory' (Weber 1986, p. 86). Since 2003 the actual military trainers and implementers of security sector reform in Iraq have operated under this Weberian rubric. Critics have used this rubric since then to criticize the failures of the 
American efforts to rebuild the Iraqi military (Al-Marashi 2008, 199-224). Even if the US military stationed in the nation undermined the Westphalian concept of state sovereignty in Iraq post-2003, Washington nonetheless argued that the Iranian-supported Shi'a militias violated Iraq's territorial integrity, political unity, and the monopoly of legitimate violence.

The policy literature also analyses the Hashd within the normative Weberian framework. A well-researched study on the Hashd by London's International Institute of Strategic Studies (IISS) writes:

In addition, through the expansion of militias that variously act as direct surrogates or over which Iran holds significant leverage through ideological affiliation, influence or practical support, Iran has deprived the Iraqi state of a monopoly on the use of force in the post-2003 era (IISS 2019)

The Brussels-based International Crisis Group (ICG), which conducted extensive on the ground interviews in Iraq among Hashd commanders, opens: 'While ISIS's territorial defeat was an important psychological boost for the Iraqi state, it did not regain for the state a monopoly over legitimate violence' (ICG 2018, p.1). In its policy assessment, it reiterates: 'The state's enduring weakness and the prime minister's own ambivalent approach have allowed the Hashd to contest Baghdad's monopoly over the use of force and to refuse giving up their uniforms, flags and weapons' (ICG 2018, p. 2). Foreign Policy, a leading publication of the Washington DC 'beltway', writes:

Kataib Hezbollah is only one of several Iran-linked armed groups active in Iraq but it has long been considered the greatest danger to the Iraqi government's aspiration to be a proper state in the classical sense-by exerting a monopoly over the use of force within its territory (Kittleson 2020).

However, aspiring to the Weberian standard in Iraq as a model or status-quo ante proves to be ill-suited, as the hybrid-plurality of armed forces has emerged as a dynamic that has become embedded in Iraq's politics. Haddad writes, 'The PMU phenomenon could turn out to be the last nail in the coffin of the dream for a Weberian Iraqi state; however, such dreams had already become somewhat farfetched long before the PMU emerged' (Haddad 2018, p. 7).

While this normative standard has been applied to delegitimize the Hashd, the US did develop a modus vivendi with their fighting units in the combat phase against ISIS from 2014 to the end of 2017 and has forged alliances with the Kurdish militias since 2003, and Arab tribal militias who revolted against the precursor to ISIS in what has been labelled the 'Sahwa' or 'Awakening' movement. Such past precedent indicates that the US had employed NSAAs as a necessity in Iraq. Mansour's policy piece, 'More Than Militias: Iraq's Popular Mobilization Forces Are Here To Stay', addresses a reality that is most likely intended for US policymakers and analysts, who would like to see the Hashd, which some DC 'beltway' circles myopically see as pro-Iranian proxies, to be disbanded. Ahram (2011) argues that states such as Iraq have little choice but to 'learn to live with militias', challenging Weberian norms by arguing that rather than US or Iraqi 
government seeking to rebuild state power, devolving authority to militias may be the 'least bad' and expedient solution to ensure security.

Comparisons of the Hashd are often made by policymakers and international media to the Lebanese Hizballah or the Iranian mass mobilization militia, the Basij, often because both paramilitary groups are Shi' a and related to the Islamic Republic, and often to demonize all three groups in the same brush stroke. In the aftermath of Soleimani's death, it was often written that he replicated the Hezbollah model in Iraq. Even within Iraq, the ICG interviewed Iraqi political figures that expressed their fear of the country's 'Hizbollahisation' via the Hashd (ICG 2018, 15). The Hashd does share with these two armed groups the status of quasi-state actors, but there are significant differences, which form the basis of the argument of this article. When the Hashd was sanctioned by the Iraqi state, it mimicked the Iranian-style parallel military dualism, with the Basij under state control, but separate from the regular military. However, this analogy only explains the parallel military structure in Iraq. The Basij is relatively cohesive compared to the Hashd, which sought to coordinate more than fifty militias, with different leaders and objectives into a single institution. The Lebanese Hizballah represented various groups, but were consolidated by the Revolutionary Guard as of 1982 and remains a centralized organisation to this day. Soleimani of the Quds Force did not establish the Hashd, but rather harnessed control of some of the Shi'a militias that emerged as a result of Arab Shi' a mobilization, that really began in 2003 with the rise of Muqtada al-Sadr, who himself rejected Iranian overtures then. Furthermore, the clerical establishments in Lebanon and Iran differ from Iraq. In Iraq, Ayatollah Sistani is the most widely followed cleric among the world's Shi'a, and with the network of the cleric Muqtada al-Sadr, both have emerged as bulwarks against the Islamic Republic's influence (Al-Marashi 2018).

This article argues that while some Hashd factions are loyal to Iran, they came together in this body as independent paramilitary groups, competing with each other for resources from both the Iranian and Iraqi states, as well as popular support in terms of votes, and subsequently jostle each other for power, particularly ministerial posts. Examining the Hashd as a decentralised Shi' a mobilisation would include the factions that are allied with Iran and those who are not. All of them however represent what Calculli (2016) calls the 'securitisation of identities'; that is a transnational social process utilised by Shi'a political elites in both Iran and Iraq to mobilise Iraq's Shi' a constituencies. This process reconciles discursively the dissonance between Shi' a actors that invoke a pan-Shi 'a imaginary, whether it is Iran or the Hashd, even if they pursue, as this article demonstrates, policies that undermine sectarian unity. In this regard, Iran and the Hashd securitised a Shi' a identity in the aftermath of the 2014 ISIS invasion, in order to bolster their own domestic legitimacy, while pan-Shi 'ism was not their principle driver for domestic and regional policy choices, which remained dictated by real political concerns and power-political rivalries.

While the securitisation of Shi' a identity allowed the Hashd to harness the energy of a greater, popular Arab Shi'a mobilisation which began prior to 2014, it eventually evolved into a state institution that was embedded in Iraq's larger pervasive culture of patronage and clientelism by including other ethnicities and religious groups. 
According to Haddad, 'This is the essence of Shi'a-centric state-building: Sunnis and non-Shi' as are welcome at the table as clients or partners provided they accept that Shi'as (in the form of Shi'a-centric political and military actors) are the senior partner' (Haddad 2018, p. 10). This inclusion allowed the Hashd to project an image of diversity, strengthening its core narrative of the vanguard of an Iraqi patriotism at the helm of a Shi'a led cross-confessional alliance against ISIS, even while the Shi'a elites contested power amongst themselves.

\section{NSAAs in Iraq's history}

Iraq's security sector is an outcome of a historical process, including the formation of militias, whether they be Kurdish forces operating in the north, to Arab tribes in the centre and south, each representing a devolution and dilution of state power, while either resisting or seeking to capture the security sector. As a response, statesponsored elite praetorian guards to all-encompassing mass-mobilization armies emerged, designed to protect the regime, not in order to dilute but redistribute state power from a national military unable to put down threats from the NSAAs in Iraq's history.

\section{Opposition militias}

Since the 1920s the Iraqi military never achieved a decisive victory against the Kurdish revolt, representing a dilution of state power over the mountainous north. From Mas'ud Barazani's Kurdistan Democratic Party (KDP) and his rival Jalal Talabani's Patriotic Union of Kurdistan (PUK) the militias they formed were integrated into the new Iraqi security apparatus to some extent, becoming the military of the KRG as of 2003, a jurisdiction in which the ISF of Baghdad's central government does not deploy. Tensions persisted between the Kurdish military forces and ISF, institutionalizing Iraq's oligopoly of violence, with problems persisting over contested jurisdictions. While these Kurdish militias morphed into the state after 2003, with American approval, nonetheless, in PUK-controlled territory, the peshmerga have worked Iranian advisers and Iranian artillery units to combat ISIS (IISS 2019). The Shi' a militias after the defeat of ISIS followed the same path by running in elections, which was met with American disapprobation.

While the Kurdish groups operated in the north of Iraq, the nation has also had a history of armed groups in the south, with Shi'a groups launching hit-andrun attacks during the Iran-Iraq War of 1980-1988, and an insurrection among the Marsh Arabs during the 1990s. In 1982, the same year the Islamic Republic sponsored the creation of Hizballah, it also created the Supreme Council of Islamic Revolution in Iraq (SCIRI) to serve as an umbrella organization, a means for the Iranian leadership to unite and control Iraqi Shi' a factions, as well as a government in exile that would assume control of Iraq after Saddam Hussein's expected demise during Iran's early military successes. Iran's Revolutionary Guard trained the SCIRI militia, the Badr Brigade, comprised of dissident Shi'a rebels and Iraqi prisoners-of-war 
(Al-Marashi 2018, p. 277). During anti-Saddam Hussein uprising in 1991 following his defeat in the Gulf War, the Badr Brigade, operating from Iran, infiltrated the south of Iraq to support the rebels (al-Jabbar 1992). The Soldier of the Imam Brigades (kata'ib jund al-imam) formed as an opposition militia during a rebellion in the marshes after 1991 (ICG 2018). The failure to suppress this rebel group represented diluted state power over this watery terrain, resulting in Hussein's decision to drain this natural habitat (Ahram 2015). After 2003 the Badr Brigade established a presence in Basra and Najaf and infiltrated the national police and other security forces, essentially becoming an arm of the newly emerging state. The Badr Brigade essentially hybridized with the ISF and the police, and took control of the Ministry of Interior, which operates its own para-military units (Redaelli 2018).

While SCIRI penetrated from outside Iraq, the most significant militia emerged within Iraq, led by the young cleric Muqtada al-Sadr and his followers. Muqtada relied on the legacy, theology, institutions, and representatives left behind by his father, Grand Ayatollah Sadiq al-Sadr, who was assassinated by Hussein's government in 1999. Sadrists were prevalent among the poorer tribes and marsh dwellers of 'Amara and Nasiriyya and in semi-urbanized areas like Saddam City (renamed Sadr City) and the poorer quarters of Basra (Cole 2003, p. 546). In these areas, the Mahdi Army would combat US military forces and sometimes its fellow Shi'a Badr Brigade for control. While SCIRI and the Mahdi Army are considered 'Shi' a militias', their demographics differed, with SCIRI formed among exiled Iraqis, opposed to the Mahdi Army, which recruited among the Shi' a urban poor who remained in Iraq during Hussein's rule. Furthermore, these two militias were rivals immediately after 2003, as SCIRI was willing to accommodate US military forces while the Mahdi Army emerged to combat them. Such tensions resulted in street battles in the shrine city of Najaf in 2007 (Marr and Al-Marashi 2017, p. 244), a rivalry that foreshadowed the intra-sectarian contest that would persist even within the Hashd as its constituent Shi' a militias jostle for power.

\section{State-sponsored elite and mass-mobilization forces}

Iraqi governments fostered two types of military units, elite guards and mass mobilization militias, representing a redistribution of state power rather than a dilution. The former developed to balance the national army with a parallel military structure, acting as a counter-coup force amongst renegade army units, as well as to suppress NSAAs. Iraq's Republican Guard served this function after the 1958 overthrow of the monarchy. As its numbers expanded during the Iran-Iraq war, Hussein established a Special Republican Guard to prevent a coup from emerging within the Republican Guard. The trend of fostering elite military units to protect the regime continued after 2003, when Prime Minister Nuri Maliki fostered a personalistic relationship with Iraq's elite Counter-Terrorism Service (CTS) (Marr and Al-Marashi 2017, pp. 279-280).

Mass-mobilization militias were also part of Iraq's security architecture. The Popular Army (al-jaysh al-sha'bi) was founded in February 1970. Replace the word 'army' (jaysh) with 'mobilization' (hashd) and the 'Popular Mobilization' shares the 
same connotations with the Popular Army. The Popular Army was subordinated to the Ba'th Party, opposed to the Ministry of Defence, as a militia to give citizens minimal military training and intense party indoctrination (Al-Marashi and Salama 2008, pp. 107-115). As a structural feature of the Iraqi state, the Hashd that came into being after the 2014 ISIS invasion served a similar function of a mass-mobilization army, called up during a national crisis. Theoretically, the Hashd was open to all sects and minorities, and while some joined, its ranks reflected a primarily Shi'a mobilization. Rather than viewing the Hashd as a uniquely sectarian phenomenon that emerged after 2014, its emblematic of mass mobilisation militias throughout Iraq's history, whether under the centralized and high-autocratic rule of Saddam Hussein or the chaotic vicissitudes of Iraq's post-2003 politics.

After declaring victory over ISIS in December 2017, Prime Minister Haider alAbadi acknowledged the hybrid security Iraq inherited from the campaign: 'I salute all the victorious: our valiant security, police and armed forces, the Popular Mobilisation Forces, our Counter-Terrorism Service, our air force and army aviation, the peshmerga and all the different formations of our armed forces' (ICG 2018, p. 1). This speech essentially granted a state imprimatur to the security fragmentation that did not emerge after the ISIS invasion of 2014, but took decades in the making, from the resistance movements to Saddam Hussein, to the groups that emerged in the aftermath of his fall.

\section{Shi'a Arab mobilization prior to 2014}

While the SCIRI militia and the Sadrists were the largest militias in the immediate aftermath of the 2003 American invasion, both groups would suffer splits leading to a proliferation of paramilitary groups on the eve of the crisis with ISIS.

As SCIRI sought to limit the power of its Badr Brigade and distance itself from Iran to reach a wider Iraqi nationalist base, the Badr Organization (munadhamat albadr) broke away in 2010 under Hadi al- 'Amiri. The Badr Organization inherited control of the networks within Iraq's traditional security forces, such as the Federal Police, the Ministry of Interior's Emergency Response Division, and the Iraqi army's $5^{\text {th }}$ and $8^{\text {th }}$ divisions (IISS 2019). This network granted what was essentially an Iranian-aligned militia/political party ability to plunder the resources of the Iraqi state before the Hashd came into being, reducing its need on the Islamic Republic for financial support. When the Hashd was called up, the Badr Organisation's militia would emerge as its largest faction. However, despite Badr's ties to Iran, it still exhibited local agency, realizing that ideological elements of Iran's Islamic Republic could not be adopted wholescale into Iraq (ibid.).

Al-Sadr's Mahdi Army emerged in 2003 to combat American forces, but had maintained its autonomy vis-à-vis Iran (Sayej 2018, p. 112). As the Islamic Republic was never able to co-opt the Sadrist militia it sponsored splinter groups from within that would depend on Iranian largesse (Mansour and Jabar 2017, p. 8). Iran supported these breakaway factions, called 'Special Groups,' in a clandestine manner to attack US forces in Iraq, and operated them as a diffuse, compartmentalized celllike networks that granted Iran both operational resilience and plausible deniability 
(IISS 2019). This model was similar to the smaller groups Iran supported in Lebanon that broke away from the pre-existing Amal Movement that would later cohere into Hizballah, but the myriad of Special Groups never achieved this cohesion. Qais al-Khaz'ali led the League of the Righteous, formed in 2006 when it abandoned the Sadrist emphasis on anti-American Iraqi nationalism and allied with the Iranian array of a Shi'a 'resistance' movements. The Hizballah Brigades formed in 2007 with Iranian support, led by Abu Mahdi Muhandis, an Iraqi who had once served as an operative for the Quds Force (ICG 2018, p. 4). 'The Movement of the GodFearing' (harakat al-nujaba) split from The League of the Righteous in 2013, led by former Mahdi Army commander Akram al-Ka'abi, who was still loyal to Iran but had personal differences with Khaz'ali. Kata'ib Sayyid al-Shuhada split from the Hizballah Brigades in 2013 (ibid.). Another group, The Imam Ali Brigades (kata'ib imam 'ali), brought the number to five Sadrist splinter groups after 2003, all claiming that they mantle of the assassinated cleric Mohammad Sadiq al-Sadr, just not his son, demonstrating how Shi'i identity was not in-and-of-itself capable of maintaining a unified Iraqi Shi' a movement. These factions also legitimized their existence because Sadr himself had disavowed violence after being defeated by the ISF and US in 2008, ordering the dismantlement of the Mahdi Army and rebranding it as a civil society organisation, 'the Peace Brigades' (sarayat al-salam) (Al-Marashi 2013).

These five Sadrist splinter militias, including the Badr Organization and the Soldier of the Imam Brigade of the marsh rebellion, collectively constituted a group of seven militias that pledged spiritual allegiance to Iranian Supreme Leader Ayatollah Khamenei and the Islamic Republic's model of governance, the 'rule of the theological jurist' (wilayat al-faqih), a post created by Ayatollah Khomeini in 1979 that fused Shi' a religious authority with the highest executive political authority in Iran. After the Hashd came into being, this faction was unofficially referred to as al-hashd al-wala' $i$, wala' being the root of the Arabic word wilayat, indicating notions of 'rulership' and 'loyalty', an ad hoc reference to the seven militias' loyalty to Khamene'i. While they did not pledge allegiance to the Iranian cleric Grand Ayatollah Ali Sistani of the Najaf hawza or 'seminary', who had rejected this political model in Iran, they still deferred to his authority and his vast sway over the Iraqi Shi' a population at large. Out of the seven, the Badr Organization and The League of the Righteous already had representatives in the Iraqi parliament, demonstrating their transition into quasi-state status prior to 2014.

The extraterritorial nature of this alliance, which was otherwise an Iranian network of affiliated groups in Iraq, emerged after the Syrian civil war as of 2011. Soleimani sought to recruit among these militias to create a foreign legion of sorts to prop up the besieged Bashar al-Asad. The Iraqi Shi'a militias initially deployed to Syria as volunteers to protect the shrine of Zaynab, the elder sister of the revered Imam Hussein, situated in Damascus. This rationale, emblematic of the securitisation of identity, provided a convenient symbol and narrative for Iraqi Shi'i volunteers fighting in Syria to defend the shrine, rather than the Syrian Ba'thist government. In reality, the Iraqi Shi' a militias would be deployed in fighting far from the shrine, including the battle for Palmyra and siege of Aleppo (Al-Tamimi 2019). Notwithstanding this pan-Shi' a narrative or securitisation of identities to legitimize their 
intervention in Syria, Sadr criticized them and Lebanon's Hizballah, declaring that Shia movements should only deploy in their national settings (Mansour and Jabar 2017, p. 17). In a further demonstration of extraterritoriality, the Badr Organization, the League of the Righteous, and Hizballah Brigades took part in these battles along with the Iran's Revolutionary Guard, the Syrian military, the Russian air force, the Lebanese Hizballah, and militias recruited from Pakistani and Afghani Shi'as.

\section{The formation of the Hashd}

By early 2014, former prime minister Maliki called on these seven paramilitary group to combat ISIS after it seized Falluja, referring to them as 'the Hashd' (Mansour and Jabar 2017, p. 6). The Hashd moniker was already in use before the ISIS invasion of Mosul in July of that year to give official sanction to the pro-Khamene'i groups operating clandestinely, since the ISF had proven unable to prevent ISIS from encroaching into Iraq. After the fall of Mosul in June 2014, the ISF collapsed entirely.

Grand Ayatollah al-Sistani's fatwa of July 2014 has been seen by commentators as the most crucial step in providing religious legitimacy for the emergence of the militias, which was not necessarily his intention. An analysis of Sistani's previous statements challenges the conventional wisdom that his fatwa of 2014 was aimed for Iraq's Shi'as to join the militias. Until then Sistani had believed in the Weberian notion that the state should have the monopoly on the use of force. Before this 2014 fatwa Sistani had stressed that the Iraqi Army served as the 'national army', demonstrating his respect for the integrity of this national, secular institution, and communicated his disdain for militias, or in his words 'special armies', particularly the pro-Khamene'i groups. As ISIS approached the outskirts of Baghdad in early summer 2014, he issued a fatwa for: 'Citizens who are able to take up arms and fight terrorists in defence of their country must volunteer and join the security forces', not 'militias' per se (Sayej 2018, pp. 112-139). His call was a 'duty to fight' (wajib al-kifah) to defend the country against ISIS (ICG 2018, p. 1). If a Shi'a had chosen the cleric as his spiritual guide, Sistani's call was an order to volunteer as a religious duty alongside praying and fasting. However, he beckoned all Iraqi citizens, not just the Shi' a, to serve as 'volunteers' (mutatawi'in) for the 'security forces', a reference to the ISF.

In tandem with Sistani's fatwa, Maliki signed an official decree that month to form the Commission for the Popular Mobilization Units (haya al-hashd al-sha'bi). The decree, while in violation of Article 9 Paragraph B of the Iraqi constitution, which states that 'the formation of military militia outside the framework of the armed forces is prohibited', allowed Maliki a legal veneer to bring the seven paramilitaries, which he had been reliant beforehand, to emerge from clandestine anonymity into a single state-sanctioned body that was separate from the collapsed ISF, allowing them to operate openly with state funding.

Because Maliki had allowed the Hashd official status, Iraqi followers of Sistani had the option of choosing to join the seven pro-Khamene'i militias. This faction was more than willing to take advantage of the ambiguity in the aftermath of 
Sistani's fatwa to accept volunteers. As these seven already existed, with military experience and Iranian funding, arms and training, many young Shi' a gravitated to them. It remains unknown as to why Sistani himself never issued a second statement clarifying his fatwa's intent, which allowed Maliki and the seven militias to use the fatwa as religious sanction. For example, as one Hashd leader said after ISIS had been mostly defeated, 'We are now closely watching the security situation. If the issue returns once again to target the Iraqi people without the government performing its duty, we would have to resort to fighting again...The fatwa still exists' (ICG 2018, p. 16). This statement indicated the blanket cover that Sistani's ruling offered the Hashd groups that had not pledged allegiance to the cleric. However, since issuing the fatwa Sistani's office refused to mention the 'Hashd' by name, instead referring to them as 'volunteers', as to not legitimize the seven militias who essentially hijacked Sistani's initiative (Mansour and Jabar 2017, 7; ICG 2018, p.4). Sadr also opposed the pro-Khamene'i wing, referring to them as the 'imprudent militias' (milishiyyat waqiha) (Mansour and Jabar 2017, 4, 14). The two clerics' ambivalence and critique demonstrate the divisions within the umbrella organization that emerged as a result of a decentralized Arab Shi' a mobilisation.

In the aftermath of the fatwa, two other distinct clusters emerged within this process. The pro-Sistani Faction, al-hashd al-marji' $i$, highlight its loyalty to the marji'iyya, a reference to the clerical seminary in Najaf. This faction consisted of ten militias, each devoted to guard a Shia holy site at a time when ISIS vowed their destruction. Four major groups emerged in Najaf, each corresponding to a religious site there, while others formed to defend sites Shi' a shrines in Kadhimiyya and Karbala (Mansour and Jabar 2017 13). Sadr ordered that his Peace Brigades take up arms again, along with two other Sadrist militias, to defend Sadr City and the Shi'a shrine in Samarra. The emergence of these two clusters was distinct from the original seven militias, as they represented more the transfer of security functions from the state to Iraq's religious civil society institutions, the shrine academies. While these two clusters operated within the Hashd structure, they had a tense relationship with the pro-Khamene'i leaders, and did not receive the same amount of funding from Iran, but rather depended on donations from the faithful.

As a result, by the end of the summer of 2014, the decentralized Arab Shi'a mobilisation led to the formation of three distinct Hashd factions, pledging allegiance to three different Shi'a religious figures: the supreme leader of Iran, Ayatollah Ali Khamene'i; Grand Ayatollah Ali al-Sistani, and the populist cleric Muqtada al-Sadr. This Shi' a Arab mobilisation after 2014 served as a microcosm of Shi' ism in general, where there is no single religious authority analogous to the Pope. Furthermore, the factions had different visions for this mobilisation process. While the first faction envisioned the Hashd's permanence even after the defeat of ISIS as an independent military institution, both al-Sistani and al-Sadr saw this as temporary mobilisation process, where upon their fighting groups would be disbanded or integrated into the ISF (ICG 2018, p. 4).

In addition to the original seven, the pro-Khamene'i cluster mobilised 15 more Shi'a militias, and at its height the Hashd consisted of 50 different groups (ICG 2018 , p. 27-8). This number reflected a plurality of groups with their own political and strategic calculations, positing them at odds with others in the umbrella 
organisation. This mobilisation raised at least 60,000 fighters with the highest estimate at 140,000 . The numbers of each PMF militias varied from a few hundred to tens of thousands combatants (Mansour and Jabar 2017, 3, 12). As the Iraqi state did not have enough reliable ISF soldiers to be garrisoned at its bases for long periods, the Kurdish peshmerga and the Hashd filled in the security vacuum in the rest of the country. Given the time, the USA needed to reconstitute the ISF, the defence of the government in Baghdad became dependent on militias, which supplemented, if not supplanted the regular military.

The next challenge after raising a significant number of fighters was coordination, and in the process of managing a decentralized Arab Shi'a mobilisation, intrasectarian rivalries erupted. The de facto administrator was Abu Mahdi Muhandis, who was in charge of allotments from the Hashd annual state budget, and favoured fellow pro-Iran groups, particularly his own Hizballah Brigades (ICG 2018, p. 4). The pro-Sistani and pro-Sadr groups accused Muhandis of manipulating recruitment and fund allocation, denying salaries to pro-Sistani and pro-Sadr factions, as well as military equipment (Mansour and Jabar 2017, 20). These intra-sectarian tensions ultimately revealed that the Hashd had become part of the greater post-2003 Iraqi contest over patronage and resource distribution.

Muhandis provided financial resources from the Iraqi state coffers as well as weapons, but battlefield military aid also came from two extra-territorial rivals: the US and Iran. While the US provided air support for the ISF in battles, including the CTS, because militias were also embedded within these units, they too enjoyed de facto American air cover. Iran, like the US, provided logistical and surveillance support, including target identification (IISS 2019). Nonetheless, even leaders of the Iran-linked Hashd, while open about their gratitude to Tehran's aid, emphasised their deployments were dictated by the Iraqi government (Ollivant and Gaston 2019).

Even prior to 2014, NSAAs penetrated bureaucracies, blurring the line between state and non-state actors, but the crisis afterwards allowed them to develop their networks. The Badr Organization, already in control of the Ministry of Interior, expanded to Transportation and Communication (Mansour and Jabar 2017, p. 19; ICG 2018, p. 9). While this influence allowed the paramilitaries to serve as patrons by offering government-level jobs to supporters, it would later hurt them after ISIS was defeated, when Shi'a-led protests emerged in 2019 to challenge their failings at governance, demonstrating that Shi' a sectarian identity was not enough to assuage other disaffected Shi'as who had perceived the Hashd in the beginning as defenders of the nation only to become complicit in government corruption afterwards.

While the Hashd was able to access state coffers, they also developed independent revenue streams from the formal and informal sector. In the lucrative reconstruction sector, while the governing institutions were marred by excessive red tape down to the provincial and municipal level, the Hashd took over contracts from ineffective state companies. In late 2017, when the national waste management company failed to collect garbage in Basra because of delayed payment, the Hashd volunteered for the role. In the Babil governorate, the Hashd installed roadside security cameras, which was originally granted to a Chinese company working with the Iraqi army and police. While the Hashd poached a contract from a Chinese company, they also engaged in unilateral trade discussions with foreign companies, including from 
China. For example, al-Khaza'li, who holds no official position, met with China's ambassador in Baghdad in March 2018 to discuss economic ties. The Hashd also takes part in black market racketeering and smuggling, particularly manning checkpoints in ISIS-liberated territories, levying 'transit fees' on travellers. Other have taken control of oil and gas smuggling in former ISIS-controlled areas (ICG 2018, pp. 11-12).

The Hashd consolidated its status as a result of an Arab Shi' a mobilisation, but with multiple sources of revenue, both official and black market, it took on the contours of another government agency in Iraq. With its independent revenue stream, the Hashd was in a position to offer patronage to Iraq's Arab Sunnis and other minorities, demonstrating even further its transformation into a state institution partaking in the clientelist politics of post-2003 Iraq. Arab Sunni politicians had sought to create their own security unit in the hybrid political system through the National Guard Act, but when their proposed law failed in parliament, they chose to join the Hashd. Arab Sunni tribes became the 'Tribal Hashd' (al-hashd al-'asha'iri) as a means of self-defence, while collecting revenue from the central government. As early as 2014, members of the Jubur tribe around Dhulu'iya allied with The League of the Righteous to combat ISIS (Haddad 2018, pp. 7-11). In the northern Salah al-Din province, Yazin al-Jaburi, the son of anti-Iranian and exiled MP Mishan alJaburi, formed the Salah al-Din Brigade of the Hashd (IISS 2019). By the end of 2016, the Nineveh province's former governor Athil al-Nujaifi, who had previously been a critic of the Hashd, incorporated his Nineveh Guards militia into the organization (Mansour and Jabar 2017, 12). While these Sunni groups received regular salaries from the Hashd, and even embedded Iranian military advisors, they were only granted minimal small-arms supplies, preventing them from emerging as rival militias within the hybrid security sector (Ollivant and Gaston 2019). Nonetheless, this dependency relationship allowed Arab Sunnis to forge relationships with Shi'a militias, it served as a 'marriage of convenience' in the common fight against ISIS, which would be an apt metaphor to describe some of the Shi'a militias' cooperation with Iran. Iran's embrace of these Sunni groups also allowed it to compete with regional and international rivals, such as Saudi Arabia, Turkey, and the US for patronage among this demographic. Such engagement dispels the myth of the Hashd or Iran pursuing a purely sectarian Arab Shi'a agenda. Furthermore, in 2018, a survey found that civilians in Sunni-majority provinces favourably viewed the Hashd as time passed, as these civilians had been in contact with the militias deployed in their areas. Arab Sunnis from the combat zones were cognizant of the Hashd's status as a multi-headed hydra and complained that while some militias were abusive, others acted in a civil manner towards them (Haddad 2018, pp. 7-11).

Iran-aligned Hashd groups additionally sought to incorporate other Iraqi ethnic and religious minorities, such as the Shabak, Turkmen, Christians, and Yazidis to enhance the nationalist credentials. The Hashd competed with KRG, which served as alternative patronage provider to Christian and Yazidis militias (IISS 2019). By the end of the military campaign against ISIS, the Hashd co-optation of these minority groups had strengthened its core narrative of the vanguard of an Iraqi patriotism, at the helm of a Shi' a led cross-confessional alliance against ISIS. While this image 
was what the Hashd sought to project to Iraqi society, divisions would occur within the body even before ISIS was defeated.

\section{The Hashd and Intra-Shia contestations of power}

Shared sectarian affiliation alone could not reconcile the Hashd with all of Iraq's Shi' a population. After the defeat of ISIS, the Hashd's behaviour and their leaders' failure to deliver effective governance had been criticized by Shi' a protestors in Basra in 2018 and by youth in the capital and the predominantly Shi' a south in 2019. While on the international level, the US, particularly under the Trump administration, had pressured the Iraqi government to curtail if not disband the Hashd, this process was occurring domestically as a result of interactions and negotiations with Iraq's domestic religious actors, voters, and protestors.

\section{Intra-Hashd tensions}

The contestation of the northern Iraqi town of Tuz Khurmato served as a microcosm of ethnic and at the same time intra-Hashd tensions. By 2016 The pro-Iranian faction of the Hashd secured the town and sponsored a Shi' a Turkmen militia to defend it from ISIS, as well as Iraqi Kurdish control (IISS 2019). In June, Badr and the League of the Righteous, considered part of the 'pro-Iran camp', fought street battles there after the latter group kidnapped a member of the former (Al-Marashi 2019). While the skirmishes were an example of clashes between militias over turf, there are also tensions within the constituent militias themselves. Hadi al- 'Amiri, leader of Badr, often bemoaned that 'half his time' is devoted to sorting out such internal disputes (ICG 2018, p. 21).

After ISIS' formal defeat, factions within the Hashd began competing against each other for power and resources. In February 2018, Muhandis, as de facto leader of the Hashd, arrested Aws al-Khafaji, leader of the Abu Fadl al- 'Abbas Brigade, another Sadrist splinter group that fought in Syria. After ISIS was defeated, Khafaji began criticizing Iranian influence in Iraq and the alleged Hashd assassination of his cousin, the novelist Ala'a Mushthub, who was also an ardent critic of Khamene'i (Mansour 2018b). This purging revealed that given an absence of an external enemy like ISIS as of 2018 and the scarcity of the spoils of the war, it was inevitable that the constituent militias of the Hashd would become competitors. The shared sectarian unity would become undone by economics, taking over checkpoints and businesses, as well as politics, fighting for ministerial posts in the May 2018 elections.

\section{The Shi'a clerical establishment}

The other clerics served as a check on the conduct of the militias of the Hashd. During the military campaign against ISIS, Sistani used his authority to constrain the Hashd when they challenged the authority of the central government. In a statement 
in May 2016, during the battle to expel ISIS from Falluja, he urged the militias to show restraint against the civilian inhabitants of the city in order to stave off human rights abuses that happened when Tikrit fell in 2015. Once ISIS was ejected from Iraq's urban centres, he still called on Iran to restrain the behaviour of its proxies. When Iran's president Rouhani visited Sistani in Najaf in March 2019, Sistani issued a veiled statement after the meeting that Iraq's sovereignty should be respected, an indirect message to Khamene'i and the Revolutionary Guards' support of factions within the Hashd (Hunter 2019). Ultimately the Hashd leaders negotiated their status between an external actor, the Revolutionary Guard and internal, Sistani, a nonstate religious authority who sought to curb Shi'a excesses and human rights abuses. While the Islamic Republic sought to dominate security governance in Iraq, it was Sistani, an Iranian cleric residing in Najaf, who served to shield the security sector from Iranian influence. One of the lobbies that emerged in Iraq calling for the demobilizing of the militias came from an unlikely source, Muqtada al-Sadr, who was the first to establish a Shi' a militia in Iraq after the American invasion. By 2017, Sadr weighed in on the demobilization of all the Hashd militias (Mansour 2018a), and like Sistani, these two non-state clerical figures bestowed legitimacy on the ISF as the primary national entity charged with the defence of Iraq.

\section{The state level}

Former Prime Minister Haydar al- 'Abadi, who replaced Maliki in the summer of 2014, maintained a delicate balance between Iran and the US, the Hashd and the regular military. During the campaign against ISIS, he maintained the final authorization of American air strikes. His denial of such support to the Hashd empowered the ISF and the CTS. The CTS also depended on American military heavy weapons, including helicopters, training, and intelligence-sharing. In fact, al- 'Abadi sought to put the CTS under his control, before he pushed for legislation to do the same for the Hashd. In August 2016, Iraq's parliament passed Law 35, the so-called CTS law, which granted this elite security force the status of a ministry, giving it autonomy in recruitment and procurement. The law granting the CTS autonomy created a blurred line in the security sector, a legal grey zone which the Hashd would later fall under (ICG 2018, pp. 18-19). Al- 'Abadi legitimized the Hashd's legal status in the November 2016 law by invoking the CTS precedent (ICG 2018, p. 13). Both laws sought to concentrate in the prime minister's office direct control over the two military units. While this law formally integrated the Hashd into the state with civilian oversight, it achieved ostensibly little to control the de-facto autonomy enjoyed by these forces on the ground. For this reason, Al-Sadr and Iraq's Arab Sunni members of parliament objected to the November law, arguing that all Hashd should be integrated within the ISF directly, and not exist as a separate military unit. Some of the Hashd leaders indicated that they did not object to integration into the Ministry of Defence as Iraqi military units, or into the Ministry of Interior as federal police, since the government was paying their salaries directly from state coffers. However, other leaders close to Iran sought autonomy while attaining legal recognition, an arrangement that allowed the militias to maintain their identities, including 
their own names and flags (Mansour 2018a), and ultimately prevailed, representing a bureaucratic rationalisation of the Arab Shi'a mobilisation.

Hashd candidates resigned from their militia posts to run in the parliamentary elections of May 2018, maintaining informal connections to their military units. Collectively, these Shi' a militias fielded candidates in a bloc led by Hadi al- 'Amiri, leader of Badr. Al-Sadr's coalition came in first, serving as Iraq's first post-2003 precedent of a leader, once at the head of sectarian militia, demobilizing and engaging in cross-sectarian politics. Coming in second was al-'Amiri's coalition and rivalry ensued with not only the Sadrists, but also within the Hashd bloc as they competed for a limited number of cabinet posts in the new government. Even though the Hashd fared relatively well in the elections, they later suffered from domestic fallout of being aligned with Iran.

\section{The Shi'a militias versus protests}

While the Hashd candidates ran on platform of having liberated the country from ISIS, Iraqis after the elections sought job creation, reliable services, and security. The Hashd's role in mobilising fighters as result of Sistani's fatwa bestowed this mobilisation with a sacred aura, their gambit to seize political and economic power undermined their legitimacy. There was only so far these militia-politicians could leverage their defeat of ISIS narrative if they failed to deliver on public goods.

Protests emerged in 2018 and again in 2019 over government corruption and failure to deliver services, which the Hashd were in part to blame. During the summer 2018, Basra protests demonstrators set fire to the headquarters of the Iran-aligned League of the Righteous, the Badr Organization, Hizballah Brigades, and Khurasani Brigades (Mamouri 2018). In October 2019, protests in Baghdad and southern Iraqi cities erupted, directing their ire at the corruption of Iraq's political elite and how Iran supported and protected the incumbent government. The spark for these protests was the dismissal of a popular military commander, Abd al-Wahab al-Sa'adi, himself a Shi'a, who commanded the CTS. Allegedly, his dismissal was at the behest of Iran, who sought to diminish the power of a commander over a military unit that was dependent on American military training, demonstrating further intraShi'a tensions within the hybrid structure of Iraq's security sector after 2014.

The constituents of the protests were Shi'a by virtue of the geographic locations of the demonstrations, such as the Nasiriyya, Najaf and Misan provinces, as well as in the Sadr City district of Baghdad. The protesters essentially consisted of Shi' a masses, who had been left behind by the economic system, revolting against the Shi'a elite, which included the Shi' a militia leaders elected to parliament. In response, some Iranian-affiliated Hashd factions allegedly targeted the protesters who for the most part are their Shi' a co-religionists (Alshamary 2019). Since 2003 Iraq had never faced an intra-Shi' a crisis on this scale, with the Hashd's domestic legitimacy waning, yet a brief respite occurred as a result of the Trump's administration's policies and Covid-19. Al-Sadr, who supported the protests, abandoned the movement to focus primarily on calling for an American withdrawal and later commanding his forces to provide medical relief. 
As a result of the protests, al- 'Abadi stepped down, and Iraq's parliament chose a new prime minister, Mustafa al-Kadhimi, a former intelligence chief. While a Shi'a, the Hizballah Brigades resisted his appointment, arguing as intelligence head he was complicit in providing the US with the information that led to the assassination of Soleimani and Muhandis (Kittleson 2020). While allegation may never be proved, the fact that the accusation was made indicates the intra-sectarian structural contestation of power between a militia embedded in the state and the official intelligence arm of the government.

\section{The Shi'a militias versus Covid-19}

The Covid-19 pandemic served as an exogenous shock to Iraq that provided an opportunity and challenge for the Iranian-aligned factions of the Hashd. The virus emerged in Iraq as of February 2020 from religious pilgrims returning from shrines in Iran. The protest movement lost momentum as result of the quarantine measures, reducing public pressure on these factions (Slim 2020). The proxy war between the US and Iran flared once again during the pandemic, as the Hizballah Brigades attacked al-Taji base north of Baghdad in March, resulting in American retaliatory air strikes (Al-Marashi 2020). However, the crisis did not escalate, an indication that Iran, as the militia's benefactor, is pressed financially by the coronavirus, as well as the US, consumed with a more immediate domestic concern.

In response to the epidemic, Sistani issued a fatwa similar to the 2014 decree, declaring that health workers fighting the outbreak are performing a religious duty akin to defending the nation from ISIS (Slim 2020). The epidemic allowed the Hashd to reinvent and rehabilitate themselves, as they could mobilise to meet this public health crisis with greater flexibility than the bloated state bureaucracies. While the Hashd proved nimbler than the Ministry of Interior, for example, in dealing with reconstruction after the defeat of ISIS, they also filled a vacuum in light of the Ministry of Health's lackluster performance, even with its help of the police and ISF. Given the Hashd's experience in setting up field hospitals during the campaign against ISIS, they were able to assist the Ministry in this regard. In terms of other logistical aid across Baghdad and the south of Iraq, particularly in the urban centres of the protest movement, the Hashd have transported medical supplies, personal protective equipment, and the deceased for burial, while distributed food to those in isolation, and sterilised public spaces. The Hashd also took part in medical information campaigns and established a psychological support network for the mental health of stressed medical personnel (Jessica and Hasan 2020).

Whether for altruistic motives or public consumption, the Hashd's medical campaign in-and-of itself demonstrates the evolution of a constellation of militias that serves as a political party in parliament and a civil society actor as well, providing public goods in light of the state's inability to do so. 


\section{Conclusions}

Both the US and the post-2003 Iraqi central government had sought to centralize the security sector, recreating a new national military based on a policy framework premised on Weberian assumptions of the importance of a singular institution, the army, to maintain a monopoly of armed force. However, both adopted a de facto strategy of devolving power to local militias and paramilitary forces, using Arab Sunni tribal militias to combat the Al-Qaida-affiliated insurgents as of 2007 and the Hashd and Kurdish militias to combat ISIS after 2014. These strategies ultimately proved to be more successful. While the US hoped that the ISF would defeat the insurgents and ISIS, and that it would rein in the power of the Hashd, the Iraqi state after 2018 consisted of the leaders of the militias as members of parliament and cabinet ministers who would have no incentive to do so. It was Iraq's religious networks and public discontent that proved more effective in this regard.

The 'Hashd' title essentially served as an imprimatur of state legitimacy to what was a decentralised process of Shi'a-Arab military mobilisation in general that began in 2003. The Hashd was never a single entity or movement, but rather an amalgam of competing groups, many of which had histories of splits and defections, each with their own ideology, internal dynamics, and strategies to maximize their position. The Arab Shi'a mobilisation was marred by structural divisions within the Hashd, with rival factions loyal to Iraqi and Iranian Shi' a clerical establishments, the latter two in a state of competition. Furthermore, certain members of the Hashd sought a role in the political process itself, more specifically running for office in the Iraqi executive and legislative branch, integrating them further into the state and making them dependent on votes and public opinion. Analysing the nature of this mobilisation allowed for a fuller understanding of each group within the Hashd and their domestic agency, rather than the seeming them as mere 'puppets' or 'proxies', a narrative found in the media and instrumentalized by the Trump administration to justify his assassination order in January 2020.

Iraq, as a case study, demonstrates the difficulties when one state, the US, tried to develop policy to deal with an array of NSAAs that would coalesce into the Hashd, which would become embedded with the Iraqi state. The US has faced similar setbacks in curbing the power of Hizballah, theoretically an NSAA, that is also embedded in the Lebanese state. Nonetheless this hybridity, in which the distinction between the state and NSAA has become increasingly blurred, has become a prevalent phenomenon in the region. While the US has vilified the Shi' a militias they are embedded in a larger history of Iraq's state building process. Ultimately Washington views Iraq's Shi' a militias as adversaries, yet they emerged as a result of American decisions made after the 2003 invasion, ranging from the disbanding the Iraqi military and the failure to adequately develop a new army prior to the 2014 ISIS invasion.

While the Hashd remains an issue related to Iraq's security governance, they have incrementally intervened in socio-economic governance, in an area in which post2003 Iraqi state lacks capacity, particularly in health care. The Covid-19 outbreak led to a drop in oil revenues and religious tourism, which deprived the Iraqi state of 
funds to address a sustained protest movement that began in October 2019, but also the state coffers that finances the Hashd. With the US and Iranian conflict spilling over on Iraqi soil, the Hashd is emblematic of the regional trend of Middle Eastern NSAAs interweaving across sovereignty, geopolitics and territoriality, even in regards to the geopolitics of a viral outbreak.

\section{Declarations}

Conflict of interest On behalf of all authors, the corresponding author states that there is no conflict of interest.

\section{References}

Ahram, A.I. 2011. Learning to Live with Militias: Toward a Critical Policy on State Frailty. Journal of Intervention and Statebuilding. 5(2): 175-192. https://doi.org/10.1080/17502977.2011.566479.

Ahram, A.I. 2015. Development, Counterinsurgency, and the Destruction of the Iraqi Marshes. International Journal of Middle East Studies. https://doi.org/10.1017/S0020743815000495.

al-Jabbar, F.A. 1992. Why the Uprisings Failed. Middle East Report 176: 2. https://doi.org/10.2307/ 3012605.

Al-Marashi, I. 2013. 'Sadrabilia: The Visual Narrative of Muqtada Al-Sadr's Islamist Politics and Insurgency in Iraq', in Haugobolle, S. and Gruber, C. (eds) Rhetoric of the Image: Visual Culture in Modern Muslim Contexts. Bloomington, IN: Indiana University Press.

Al-Marashi, I. 2018. 'Reconceptualizing Shi' ism and Notions of the "Shi' a Crescent": A History of IntraShi'a Tensions in Iraq vis-à-vis the Islamic Republic of Iran before and after the 2011 Uprisings', in Rivetti, P. and Kraetzschmar, H. (eds) Islamists and the Politics of the Arab Uprisings: Governance, Pluralisation and Contention. Edinburgh, UK: Edinburgh University Press.

Al-Marashi, I. 2019. The Future of Iraq's Security. In Anders Jägerskog, ed. A.S. Michael Schulz, 96-110. Routledge Handbook on Middle East Security. London: Routledge.

Al-Marashi, I. 2020. 'Coronavirus, US attacks and low oil prices: Can Iraq cope?', Middle East Eye, 16 March. Available at: https://www.middleeasteye.net/opinion/coronavirus-us-attac ks-and-low-oil-prices-can-iraq-cope.

Al-Marashi, I., and S. Salama. 2008a. Iraq's Armed Forces: An Analytical History. London and New York: Routledge.

Al-Marashi, I., and S. Salama. 2008b. Iraq's armed forces: An analytical history. Iraq's Armed Forces: An Analytical History. https://doi.org/10.4324/9780203928769.

Al-Tamimi, A. J. 2019. 'The Return of Iraqi Shi'i Militias to Syria', Middle East Institute, 16 March. Available at: www.mei.edu/content/at/return-iraqi-shi'i-militias-syria.

Alshamary, M. 2019. 'Iraqi protesters are mostly Shiite. And this identity is shaping how they protest.', Washington Post, 14 December. Available at: https://www.washingtonpost.com/politics/2019/12/14/ iraqi-protesters-are-mostly-shiite-this-identity-is-shaping-how-they-protest/.

Calculli, M. 2016. Middle East security: Conflict and securitization of identities'tle. In International Relations of the Middle East, ed. L. Fawcett, 219-235. Oxford: Oxford University Press.

Cole, J. 2003. The United States and Shi' ite Religious Factions in Post-Ba'thist Iraq. Middle East Journal 57(4): 543-566. https://doi.org/10.2307/4329939.

Haddad, F. 2018. 'Understanding Iraq's Hashd al-Sha'bi'. The Century Foundation. Available at: https:// production-tcf.imgix.net/app/uploads/2018/03/03152358/understanding-iraqs-hashd-al-shabi.pdf.

Hunter, S. 2019. 'What Did Rouhani Really Get From His Iraq Visit?', Lobelog, 15 March. Available at: https://lobelog.com/what-did-rouhani-really-get-from-his-iraq-visit/.

International Crisis Group (ICG). 2018. 'Iraq's Paramilitary Groups: The Challenge of Rebuilding a Functioning State', July. Available at: https://d2071andvip0wj.cloudfront.net/188-iraqs-paramilita ry-groups_0.pdf. 
International Institute of Strategic Studies (IISS). 2019. 'Iran's Networks of Influence in the Middle East', November. Available at: https://www.iiss.org/publications/strategic-dossiers/iran-dossier/ iran-19-06-ch-4-iraq.

Jessica and M. W. Hasan. 2020. 'Iraq's Popular Mobilisation Forces and the COVID-19 Pandemic: A new raison d'être?', London School of Economics. Available at: https://blogs.lse.ac.uk/mec/2020/04/ 29/iraqs-popular-mobilisation-forces-and-the-covid-19-pandemic-a-new-raison-detre/.

Kittleson, S. 2020. 'A Powerful Iran-Backed Militia Is Losing Influence in Iraq', Foreign Policy, 20 May. Available at: https://foreignpolicy.com/2020/05/11/a-powerful-iran-backed-militia-is-losing-influ ence-in-iraq/.

Mamouri, A. 2018. 'Mortars hit Iraq's Green Zone as violent protests continue', Al-Monitor, September.

Mansour, R. 2018a. 'More Than Militias: Iraq's Popular Mobilization Forces Are Here To Stay', War on the Rocks, 3 April. Available at: https://warontherocks.com/2018/04/more-than-militias-iraqs-popul ar-mobilization-forces-are-here-to-stay/.

Mansour, R. 2018b. 'Why Are Iraq's Paramilitaries Turning on Their Own Ranks', Washington Post, 18 February. Available at: https://www.washingtonpost.com/news/monkey-cage/wp/2019/02/18/whyare-iraqs-paramilitaries-turning-on-their-own-ranks/.

Mansour, R. and F. A. Jabar. 2017. 'The popular mobilization forces and Iraq's future', Carnegie Middle East Center, April.

Marr, P., and I. Al-Marashi. 2017. The Modern History of Iraq, 4th ed. Boulder, CO: Westview Press.

Ollivant, D. and E. Gaston. 2019. 'The Problem with the Narrative of "Proxy War" in Iraq', Warontherocks.com, 31 May. Available at: https://warontherocks.com/2019/05/the-problem-withthe-narrative-of-proxy-war-in-iraq/.

Redaelli, R. 2018. 'The Osmotic Path: The PMU and The Iraqi State', Italian Institute for International Political Studies (ISPI), October.

Sayej, C.M. 2018. Patriotic Ayatollahs: Nationalism in Post-Saddam Iraq. Ithaca, NY: Cornell University Press.

Slim, R. 2020. 'COVID-19 and the Middle East', Middle East Institute, 18 March. Available at: https:// www.mei.edu/blog/covid-19-and-middle-east\#iraq.

Weber, M. 1986. 'Politics as vocation', in Gerth, H. H. and Mills Wright, C. (eds) From Max Weber: Essays in Sociology. New York, NY: Oxford University Press.

Publisher's Note Springer Nature remains neutral with regard to jurisdictional claims in published maps and institutional affiliations. 